\title{
Genome
}

\section{Genes and proteins associated with ribeye area and meat tenderness in a commercial Nellore cattle population}

\begin{tabular}{|c|c|}
\hline Journal: & Genome \\
\hline Manuscript ID & gen-2020-0163.R2 \\
\hline Manuscript Type: & Article \\
\hline $\begin{array}{r}\text { Date Submitted by the } \\
\text { Author: }\end{array}$ & $21-$ Nov-2021 \\
\hline Complete List of Authors: & $\begin{array}{l}\text { Frezarim, Gabriela; School of Agricultural and Veterinary Studies, Animal } \\
\text { Science } \\
\text { Fonseca, Larissa; School of Agricultural and Veterinary Studies, Animal } \\
\text { Science } \\
\text { Salatta, Bruna; School of Agricultural and Veterinary Studies, Animal } \\
\text { Science } \\
\text { Silva, Danielly; José do Rosário Vellano University } \\
\text { Bresolin, Tiago; University of Wisconsin-Madison } \\
\text { Seno, Leonardo; Federal University of Grande Dourados } \\
\text { Barufatti, Alexéia; Federal University of Grande Dourados } \\
\text { Ferro, Jesus; School of Agricultural and Veterinary Studies } \\
\text { Albuquerque, Lucia; School of Agricultural and Veterinary Studies }\end{array}$ \\
\hline Keyword: & beef cattle, biological processes, gene expression, meat quality, Zebu \\
\hline $\begin{array}{r}\text { Is the invited manuscript for } \\
\text { consideration in a Special } \\
\text { Issue? : }\end{array}$ & Not applicable (regular submission) \\
\hline
\end{tabular}

\section{SCHOLARONE Manuscripts}


6

$7 \quad{ }^{1}$ Department of Animal Science, Faculty of Agricultural and Veterinarian Sciences, São

8 Paulo State University (UNESP), Jaboticabal, SP, Brazil.

9

\section{Genes and proteins associated with ribeye area and meat tenderness in a} commercial Nellore cattle population

Gabriela B. Frezarim ${ }^{1}$, Larissa F.S. Fonseca ${ }^{1}$, Bruna M. Salatta ${ }^{1}$, Danielly B. S. Silva ${ }^{1,2}$, Tiago Bresolin ${ }^{1,3}$, Leonardo de Oliveira Seno ${ }^{4}$, Alexéia Barufatti ${ }^{5}$, Jesus Aparecido Ferro $^{6,7}$, Lucia G. de Albuquerque ${ }^{1,7^{*}}$

2José do Rosário Vellano University, Alfenas, MG, Brazil.

${ }^{3}$ Department of Animal Science, University of Wisconsin, Madison, USA.

$1{ }^{4}$ Faculty of Animal Science, Federal University of Grande Dourados, Dourados, Brazil.

${ }^{5}$ Faculty of Biological Sciences, Federal University of Grande Dourados, Dourados, Brazil.

${ }^{6}$ Department of Technology, Faculty of Agricultural and Veterinarian Sciences, São Paulo State University (UNESP), Jaboticabal, SP, Brazil.

${ }^{7}$ National Council of Technological and Scientific Development (CNPq), Brazil

17 * Corresponding author: gabibonfa@hotmail.com 
Abstract: Despite several studies on genetic markers and differently expressed genes related to ribeye area (REA) and tenderness traits in beef cattle, there is divergence in the results regarding the genes associated with these traits. Thirteen genes that had been associated or have biological functions that may influence such phenotypes were included in this study. A total of five genes for REA (IGF-1,IGF-2, MSTN, NEDD4, and UBE4A) and eight genes for meat tenderness (CAPN1, CAPN2, CAST, HSPB1, DNAJA1, FABP4, $S C D$, and PRKAG3) were selected from previously studies in beef cattle. Genes and its respective proteins expression were validated in a commercial population of Nellore cattle using quantitative real-time PCR (RT-qPCR) and advanced mass spectrometry (LC / MS-MS) techniques, respectively. MSTN gene was upregulated in animals with low REA. CAPN1, CAPN2, CAST, HSPB1, and DNAJA1 genes were upregulated in animals with tougher meat. The proteins translated by these genes were not differentially expressed. Our results could confirm the potential of some studied genes as biomarkers for carcass and meat quality in Nellore cattle.

Keywords: beef cattle, biological processes, gene expression, meat quality, zebu.

(1)

(1)




\section{Introduction}

The Brazilian beef cattle expansion is directly associated with the competitiveness of the productive sector. Despite production and reproduction traits are crucial for the beef cattle operations, carcass and meat quality traits may play an important role in the success of the entire beef industry. Although Nellore cattle, the most important breed in Brazil, present adaptability and rusticity in tropical regions, they do not have the same carcass and meat quality when compared with European breeds (Crouse et al.,1989; Wheeler et al., 1994; Ferraz e Felício., 2010; Lage et al., 2012; Pereira et al., 2015). Thus, selection for increasing animal performance as well as to improve carcass and meat quality is necessary to meet consumer market demand.

Several studies have been conducted to identifying genetic markers and differentially expressed genes related to carcass and meat quality traits in different species (Pan, 2003; Lehnert et al., 2007; Fonseca et al., 2015; Fonseca et al., 2017; Li et al., 2016; Piórkowska et al., 2016; Vignato et al., 2017; Fang et al., 2018; Horodyska et al., 2018; Silva et al., 2020). In beef cattle, however, due to genetic and environmental factors, there is a wide divergence across breeds regarding the genes associated with such traits. Identify differently expressed genes, therefore, would provide a better understanding of muscle physiological processes and their influence on meat quality traits (Bernard et al., 2007; Carvalho et al., 2012; Fonseca et al., 2017; Malheiros et al., 2018, Silva et al., 2020).

Even though several large-scale gene expression tools have been developed, the realtime PCR technique (qRT-PCR) is known as the most effective and accurate method for identification of key genes. (Heid et al., 1996). Moreover, once proteins are the final molecules resulting from the central dogma of biology, studying the profile of differential gene expression at the mRNA and protein level may help to understand biological processes and allow scientists to find possible biomarkers that could contribute to the 
selection of quality beef animals (Bendixen et al., 2005, Hollung et al., 2007). Thus, this study aimed to identify and validate differentially expressed genes for rib eye area (REA) and meat tenderness found in the literature and verify whether they are being translated into differentially expressed protein.

\section{Materials and Methods}

\subsection{Sample collection}

Meat samples were collected from 189 Nellore bulls belonged to São Marcelo farm, located in Tangará da Serra/MT - Brazil, which is part of the Cia de Melhoramento animal breeding program. Animals were raised on pasture, finished in a feedlot for about 90 days, and slaughtered in a commercial slaughterhouse with approximately 24 months of age. Slaughtering procedures followed the Sanitary and Industrial Inspection Regulation for Animal Origin Products from the Ministry of Agriculture, Livestock, and Supply. Tissue samples from Longissimus thoracis muscle were collected during slaughter and stored in $15 \mathrm{~mL}$ falcon tubes containing $5 \mathrm{~mL}$ of RNA holder (BioAgency, Sao Paulo, SP, Brazil). The samples were stored in an ultra-low freezer at $-80{ }^{\circ} \mathrm{C}$ until RNA and proteins extraction was performed. After 24 to 48 hours of cooling in a cold chamber, samples from Longissimus thoracis muscle, between the 12th and 13th ribs of the left side of each carcass were collected and frozen at $-20{ }^{\circ} \mathrm{C}$. Steak samples of 2.54 $\mathrm{cm}$ thick were used to measure ribeye muscle area (REA), according to USDA Quality Grade (1989), and meat tenderness, trough Warner-Bratzler shear force (WBSF) methodology proposed by Wheeler et al. (1995).

The phenotypes obtained were adjusted for the fixed effects of contemporary groups (CG) and age of animal at slaughter, as linear covariate. The CG were defined according to year and farm of birth, management group and farm at yearling, and slaughtered date. Fixed effect solutions were estimated through a single trait animal 
model using airemlf90 software (Misztal et al., 2014). The dataset of 4.694 and 4.839 animals for rib eye area (REA) and meat tenderness, respectively, were considered in the analysis.

After pre-adjust the phenotypes, 12 extreme animals were selected for each trait (REA and meat tenderness). To verify the statistical difference between the extreme groups, the Student's T test was performed using software R (Table 1).

Table 1: Number of animals $(\mathrm{N})$, means, standard error (SE), minimum and maximum for extremes pre-adjusted of meat tenderness $\left(\mathrm{kgf} / \mathrm{cm}^{2}\right)$ and ribeye area $\left(\mathrm{cm}^{2}\right)$ traits in Nellore cattle.

\begin{tabular}{lcccccc}
\hline & N & Means & SE & Minimum & Maximum & p-value \\
\hline REA* high $^{*}$ & 12 & 82.93 & 3.91 & 79.14 & 91.51 & \multirow{2}{*}{$2.09 \mathrm{E}^{-11}$} \\
REA* low & 12 & 58.40 & 1.41 & 55.68 & 60.09 & \\
Tender Meat & 12 & 3.31 & 0.69 & 1.99 & 4.12 & \multirow{2}{*}{$8.99 \mathrm{E}^{-15}$} \\
Tough Meat & 12 & 9.16 & 0.54 & 8.66 & 10.05 & \\
\hline
\end{tabular}

*Ribeye area.

\subsection{Target genes}

Thirteen genes that had been associated or that have biological functions that may influence rib eye area and meat tenderness, were chosen for validation (Table 2). Furthermore, differentially expressed genes in muscle tissue described in published papers or public database were considered in this study.

\subsubsection{Extraction of total RNA and quantitative PCR real-time}

Fifty $\mathrm{mg}$ of muscle tissue previously stored in RNAlater solution was used (Ambion, ThermoFisher Scientific, USA) to extract the total RNA using the extraction kit RNeasy Lipid Tissue Mini (Qiagen, Valencia, CA, EUA), according to instructions from manufacturers. RNA concentration and purity were evaluated using a NanoDrop 1000 Spectrophotometer (Thermo Fisher Scientific, Santa Clara, CA, EUA, 2007) by measuring absorbance ratio of 260,280 , and $230 \mathrm{~nm}$. In addition, the Bioanalyzer determined the RIN (RNA integrity number) index, considering values equal or higher than 7 as satisfactory (Schroeder et al., 2006). The absence of contamination for each 
sample with genomic DNA was confirmed in a Qubit巴 2.0 Fluorometer (Invitrogen, Carlsbad, CA, USA, 2010) using Qubit brDNA Assay Kit (Invitrogen). The complementary DNA (cDNA) strand synthesis was performed using SuperScript III FirstStrand Synthesis SuperMix for qRT-PCR Kit (Invitrogen, Carlsbad, CA, USA), according to instructions from manufacturers.

Nucleotide sequences used to design the primers were obtained from mRNA sequences present in GeneBank Database (htpp: //www.ncbi.nlm.nih.gov). Thirteen primer pairs were designed for the target genes studied here including: IGF-1, IGF-2, MSTN, UBE4A, and NEDD4 for REA and CAPN1, CAPN2, CAST, HSPB1, DNAJA1, FABP4, SCD, and PRKAG3 for meat tenderness (Table 3). Moreover, three reference genes were selected from literature to normalize the reactions: Beta Actin (ACTB), Glyceraldehyde 3-phosphate dehydrogenase $(G A P D H)$, and hypoxanthine phosphoribosyltransferase 1 (HPRT1) (Table 3). For oligonucleotide design, the Primer Express 3.0 program (Applied Biosystems, Foster, CA, USA, 2004) was used. Subsequently, the sequence specificity of the chosen oligonucleotides was verified using NCBI BLASTN algorithm (http://www.ncbi.nlm.nih.gov/BLAST) related to the bovine genome.

The qRT-PCR reactions were performed on the Applied Biosystems ${ }^{\mathrm{TM}} 7500$ RealTime PCR System, using the SYBR Green Master Mix. Primer concentrations were determined by titration. For REA related genes the combinations of forward and reverse primers in $\mathrm{nM}$ were: IGF-1 (100/100), IGF-2 (100/100), MSTN (300/300), NEDD4 $(100 / 100)$ and $U B E 4 A(300 / 300)$. For the tenderness related genes, the combinations of forward and reverse primers in nM were: CAPN1 (600/600), CAPN2 (100/100), CAST (300/300), DNAJA1 (100/100), HSPB1 (600/600), FABP4 (300/300), SCD (300/300), and PRKAG3 (600/600). 
150 Table 2: Genes related to ribeye area and meat tenderness.

\begin{tabular}{|c|c|c|c|c|}
\hline & GENE & Author & Breed & Method \\
\hline \multirow{10}{*}{$\begin{array}{l}\text { Ribeye } \\
\text { area. }\end{array}$} & \multirow[t]{2}{*}{$I G F-1$} & Guo et al., (2015) & Brahman & Microarray \\
\hline & & Sadkowski et al., (2009) & Limousin & Microarray \\
\hline & \multirow[t]{2}{*}{$I G F-2$} & Silva et al., (2020) & Nellore & RNAseq $^{2}$ \\
\hline & & Goodall andSchmutz et al., (2007) & Bos taurus & Genotyping ${ }^{3}$ \\
\hline & \multirow[t]{3}{*}{ MSTN } & Busato et al., (2016) & Brahman & qRT-PCR ${ }^{1}$ \\
\hline & & Silva et al., (2020) & Nellore & RNAseq $^{2}$ \\
\hline & & Zhang et al., (2011) & Quinchuan & Microarray \\
\hline & \multirow[t]{2}{*}{ NEDD4 } & Vignato et al., (2017) & Nellore & RNAseq $^{2}$ \\
\hline & & Júnior et al., (2015) & Nellore & GWAS $^{4}$ \\
\hline & $U B E 4 A$ & Vignato et al., (2017) & Nellore & RNAseq $^{2}$ \\
\hline \multirow{28}{*}{$\begin{array}{l}\text { Meat } \\
\text { tenderness. }\end{array}$} & \multirow[t]{8}{*}{$C A P N 1$} & Pinto et al., (2010) & Nellore & Genotyping ${ }^{3}$ \\
\hline & & Page et al., (2002) & Simmental x Angus & Genotyping $^{3}$ \\
\hline & & Castro et al., (2017) & Nellore & $\mathrm{GWAS}^{4}$ \\
\hline & & White et al., (2005) & Brahman & Genotyping $^{3}$ \\
\hline & & Curi et al., (2009) & Several Breeds & ARMS - $\mathrm{PCR}^{5}$ \\
\hline & & Corazzin et al., (2013) & Simmental & qRT-PCR ${ }^{1}$ \\
\hline & & Tizioto et al., (2013) & Nellore & $\mathrm{GWAS}^{4}$ \\
\hline & & Nattras et al., (2014) & Brahman/Angus & qRT-PCR ${ }^{1}$ \\
\hline & \multirow[t]{3}{*}{ CAPN2 } & Moreno et al., (2009) & Colombian Creole & PCR-RFLP ${ }^{6}$ \\
\hline & & Tizioto et al., (2013) & Nellore & GWAS $^{2}$ \\
\hline & & Castro et al., (2017) & Nellore & GWAS $^{2}$ \\
\hline & \multirow[t]{7}{*}{ CAST } & Schenckel et al., (2006) & Several breeds & PCR-RFLP 3 \\
\hline & & Pinto et al., (2010) & Nellore & Genotyping ${ }^{3}$ \\
\hline & & Nattras et al., (2014) & Brahman/Angus & qRT-PCR ${ }^{1}$ \\
\hline & & Curi et al., (2009) & Several Breeds & ARMS - PCR 5 \\
\hline & & Magalhães et al. (2016) & Nellore & $\mathrm{GWAS}^{4}$ \\
\hline & & Bernard et al., (2007) & Charolais & Microarray \\
\hline & & Castro et al., (2017) & Nellore & $\mathrm{GWAS}^{4}$ \\
\hline & \multirow[t]{4}{*}{ HSPB1 } & Malheiros et al., (2018) & Nellore & qRT-PCR ${ }^{1}$ \\
\hline & & Hocquette et al., (2012) & Charolais & Microarray \\
\hline & & Bernard et al., (2007) & Charolais & Microarray \\
\hline & & Corazzin et al., (2013) & Simmental & qRT-PCR ${ }^{1}$ \\
\hline & \multirow[t]{3}{*}{$D N A J A 1$} & Bernard et al., (2007) & Charolais & Microarray \\
\hline & & Malheiros et al., (2018) & Nellore & qRT-PCR ${ }^{1}$ \\
\hline & & Hocquette et al., (2012) & Charolais & Microarray \\
\hline & $F A B P 4$ & Zhao et al., (2012) & Angus & Microarray \\
\hline & $S C D$ & Vignato et al., (2017) & Nellore & RNAseq $^{2}$ \\
\hline & PRKAG3 & Bongiorni et al., & Several Breeds & RNAseq $^{2}$ \\
\hline
\end{tabular}
association study ${ }^{5}$ Amplification- refractory mutation system, ${ }^{6}$ Restriction fragment 
Table 3: Forward (F) and reverse (R) primer oligonucleotides sequences used in qRT PCR to obtain amplicons for ribeye area, meat tenderness and reference genes.

\begin{tabular}{|c|c|c|c|c|}
\hline GENE & $\begin{array}{c}\text { Number of } \\
\text { Access (GENBANK) }\end{array}$ & Sequence $\left(5^{\prime}-3^{\prime}\right)$ & $\begin{array}{c}\text { MT }^{1} \text { of } \\
\text { Amplicon } \\
\left({ }^{\circ} \mathbf{C}\right)\end{array}$ & $\begin{array}{c}\text { Size of } \\
\text { Amplicon } \\
\left(\mathbf{p b}^{2}\right)\end{array}$ \\
\hline$I G F-1 F$ & & TCAGCAGTCTTCCAACCCAAT & & \\
\hline$I G F-1 R$ & NM_001077828.1 & GCACAGGGCCAGATAGAAGAGA & 81 & 72 \\
\hline$I G F-2 F$ & & TGTGCAGCTGAGACCGAATT & & \\
\hline$I G F-2 R$ & NM_174087.3 & GGAGCACGGAACAGGAAAAC & 82 & 77 \\
\hline MSTN-F & & CGGCTCCTTGGAAGACGAT & & \\
\hline$M S T N-R$ & NM_001001525.3 & AGACTCCGTGGGCATGGTAAT & 83 & 67 \\
\hline NEDD4-F & & CCCTTCAGGACAACCTAACAGATG & & \\
\hline$N E D D 4-R$ & NM_010812047.2 & TCGGTTGTCAACACTTTCTGTTTC & 79 & 113 \\
\hline$U B E 4 A-F$ & & GACTGAGCCACAGATGCTACAAA & & \\
\hline$U B E 4 A-R$ & NM_001098999 & TGCCTATGGCCAGCTGAAC & 81 & 80 \\
\hline$C A P N 1-F$ & & CTCTCAGGAGGCAGCACATCT & & \\
\hline$C A P N 1-R$ & NM_174259.2 & CTTGCGCAGCTCGTACCA & 85 & 75 \\
\hline$C A P N 2-F$ & & TCTTTCAACGACTTCCTGAGACACTA & & \\
\hline$C A P N 2-R$ & NM_001103086.1 & ACTTCTTGTAGCTGTCACTGGTGAGT & 80 & 88 \\
\hline CAST-F & & TGCCTTGTCATCCGACTTCAC & & \\
\hline$C A S T-R$ & NM_001025569.1 & CCCCAGCTGACTGAGCTTTT & 79 & 104 \\
\hline HSPBI-F & & GAACAGCCGGAAACAAGTAAAGA & & \\
\hline$H S P B 1-R$ & NM_001025569.1 & GGGTGAGGATGTCCAGTGATG & 83 & 76 \\
\hline$D N A J A 1-F$ & & GGAGGAGAACAGGCAATTAAAGAA & & \\
\hline$D N A J A 1-R$ & NM_001015637.1 & ACAACGTTTTTACCTCTCСТCTCTCT & 80 & 125 \\
\hline$S C D-F$ & & TGGTCAGCTCCCCTCATAGTAAG & & \\
\hline$S C D-R$ & NM_173959.4 & GCTCACCACCATACCACCAAT & 79 & 58 \\
\hline$F A B P 4-F$ & & CTGCCACCAGAGTTTATGAGAGA & & \\
\hline$F A B P 4-R$ & NM_174314.2 & ACCAACATAACCATATCAAAATCAG & 78 & 64 \\
\hline$P R K A G 3-F$ & & CCCTTTTGTAGGTTCCGCTCTT & & \\
\hline PRKAG3-R & NM_001162421 & GCTTCTGGGAGCACAAGCA & 84 & 80 \\
\hline$G A P D H-F$ & & CCGTTCGACAGATAGCCGTAA & & \\
\hline$G A P D H-R$ & NM_001034034 & CGACCTTCACCATCTTGTCTCA & 83 & 69 \\
\hline BACTIN-F & & CAGCAAGCAGGAGTACGATGAG & & \\
\hline$B A C T I N-R$ & NM_177945 & AAGGGTGTAACGCAGCTAACAGT & 83 & 85 \\
\hline HPRTI-F & & TGATGAAGGAGATGGGTGGC & & \\
\hline$H P R T 1-R$ & NM_001034035 & CCAACAGGTCGGCAAAGAAC & 83 & 81 \\
\hline
\end{tabular}

$158{ }^{1}$ Melting temperature; ${ }^{2}$ : base pairs

159 For the amplification of the reference genes, the selected concentrations in $\mathrm{nM}$ 160 were: GAPDH (300/300), BETA ACTIN (300/300), and HPRT1 (100/100). Reactions by 161 titration and standard curve were performed as described by Fonseca et al. (2015). 
Edition statistical software (https://www.sas.com/software/university-edition/download-

software.html). For data normalization, a geometric mean of $\mathrm{Ct}$ value obtained from the three reference genes (GAPDH, BETA ACTIN, and HRPT1) was established as suggested by Vandesompele et al. (2002). The relative expression of the target genes (IGF-1, IGF-2, MSTN, NEDD4, UBE4A CAPN1, CAPN2, CAST, DNAJA1, HSPB1, $A S A H 1$ and PRKAG3) was calculated as proposed by Steibel et al. (2009), according to the following model:

$$
y_{g i k r}=t_{i g}+d_{i k}+e_{g i k r}
$$

where $\boldsymbol{y}_{\boldsymbol{g} \boldsymbol{i k r}}$ is the Ct obtained from the thermocycler for gene g (geometric mean of the reference genes and target gene) in the $\mathbf{r}$ the well of the plate (referring to the technical replicate) in a sample obtained from animal k of treatment $\mathrm{i}$; $\boldsymbol{t}_{\boldsymbol{i}}$ is the effect of treatment $\mathrm{i}$ on gene expression $\mathrm{g} ; \boldsymbol{d}_{\boldsymbol{i} \boldsymbol{k}}$ is the random sampling specific effect which captures the differences, such as differential extraction or amplification efficiencies between samples; and $\boldsymbol{e}_{\boldsymbol{g i k r}}$ is the residual effect.

\subsection{Proteomic analyses}

\subsubsection{Sample preparation}

The samples were initially washed with phosphate buffered saline (PBS). The tissue was weighed, frozen in liquid nitrogen and pressed in a mortar. Protein extraction was performed by adding a buffer containing $8 \mathrm{M}$ urea, $0.15 \mathrm{M}$ Tris- $\mathrm{HCl}$ buffer ( $\mathrm{pH} 8.8$ ), O.G detergent $0.5 \%$ (1-S-Octyl- $\beta$-D-Thioglucopyranoside) and $10 \mu \mathrm{L}$ of Protease Inhibitor Cocktail (Sigma-Aldrich, USA). Samples were sonicated in 3 cycles of 1 minute, followed by centrifugation at $12,000 \times \mathrm{xg}$ for $5 \mathrm{~min}$ at $4{ }^{\circ} \mathrm{C}$. The protein quantification was performed using Bradford method with Protein Assay Dye Reagent Concentrate (BioRad, USA) (Bradford, 1976) and the standard curve was performed using different 
dilutions of BSA (bovine serum albumin). The samples were distributed in duplicate in microplates and the absorbance at $595 \mathrm{nM}$ was read in a spectrophotometer (Molecular Devices, SpectraMax Plus 384).

Samples preparation $(50 \mu \mathrm{g})$ for advanced mass spectrometry was conducted following three main steps: protein reduction and alkylation, enzymatic digestion of proteins with trypsin, and clean up/desalting of the samples. Each sample was submitted to disulfide bonds reduction of the protein through the addition of DTT (dithiothreitol) in a proportion of $1 \mathrm{mg}$ of DTT/mg protein and incubated for $2 \mathrm{~h}$ at room temperature. Then, alkylating IA (iodoacetamide) was added in a proportion of $3 \mathrm{mg}$ IA/mg of protein and incubated for $1 \mathrm{~h}$ at room temperature in the dark.

The volume of the sample was diluted five times in $0.1 \mathrm{M}$ solution of ammonium bicarbonate $(\mathrm{pH} \geq 8.0)$ resulting in a final volume of $500 \mu$. The sample was incubated with $1 \mu \mathrm{g}$ trypsin (Promega, Madison, Wiscousin, USA) at $37^{\circ} \mathrm{C}$ overnight. Before the application of samples into mass spectrometer, clean-up / desalting was performed using the OASIS HLB cartridge 1cc column, according to recommendation of the manufacturer. Then, the samples were dried in speed vac and applied to a mass spectrometer.

\subsubsection{Data Processing}

From each sample, $1 \mu \mathrm{g}$ of each sample was injected into an OrbiTrap Fusion mass spectrometer and the data obtained were automatically processed by the Computational Proteomics Analysis System (CPAS) (Rauch et al., 2006). The identified peptides were grouped into proteins using the "Protein Prophet" algorithm. A list of tags with an error rate of less than $2.0 \%$ was created. For reference, we used the database: Bovine Proteome Uniprot (https://www.uniprot.org / proteomes / UP000009136). The comparative and quantitative analysis was performed using the number of peptide-spectrum matches 
212 observed for each peptide, which provides an estimation of abundance, also known as 213 "spectral counting".

\subsubsection{Statistical analysis of mass spectrometry data}

Statistical analysis of differentially expressed proteins (DEP) was performed using the msmsTests package in R (Gregory et al., 2019), where the negative binomial of the edgeR package is available. The package uses statistical tests for label-free LC-MS/MS data by spectral counts, to discover differentially expressed proteins between two biological conditions. The multiple testing correction false discovery rate (FDR $<0.05)$ estimation was used.

\section{Results}

For REA, the expression level of the MSTN gene between the high and low REA the genes in muscle tissue showed that expression of the MSTN gene was 1.76 times higher in low REA animals (Table 4). For meat tenderness, CAPN1, CAPN2, CAST, $H S P B 1$, and DNAJA1 genes showed significantly distinct expression between the analyzed groups for tender and tough meat (p-value $<0.05)$ (Table 5). The expression level of the $C A P N 1, C A P N 2, C A S T, H S P B 1$, and $D N A J A 1$ genes were respectively 1.47 , $1.53,1.49$ and 1.50 times higher in tough meat when compared with group of tender meat. $1)$. 
236 Table 4: Expression of $I G F-1, I G F-2, M S T N$, NEDD4 and UBE4A genes in Longissimus

237 Thoracis muscle of Nellore cattle from extreme groups for ribeye area trait.

\begin{tabular}{|c|c|c|c|c|}
\hline Gene & $\begin{array}{l}\text { Group } \\
\text { (REA) }\end{array}$ & Fold Change $^{1}$ & Standard error & p-value \\
\hline \multirow{2}{*}{$I G F-1$} & High & 1,00 & 0.29 & \multirow{2}{*}{0,8745} \\
\hline & Low & 0.93 & 0.29 & \\
\hline \multirow{2}{*}{$I G F-2$} & High & 1,00 & 0.23 & \multirow{2}{*}{0,3971} \\
\hline & Low & 0.71 & 0.23 & \\
\hline \multirow{2}{*}{ MSTN } & High & 1,00 & 0.24 & \multirow{2}{*}{$0.0132^{*}$} \\
\hline & Low & 1.76 & 0.24 & \\
\hline \multirow{2}{*}{ NEDD4 } & High & 1,00 & 0.19 & \multirow{2}{*}{0.3429} \\
\hline & Low & 1.14 & 0.19 & \\
\hline \multirow{2}{*}{$U B E 4 A$} & High & 1,00 & 0.22 & \multirow{2}{*}{0.4224} \\
\hline & Low & 1.15 & 0.22 & \\
\hline
\end{tabular}

Table 5: Expression of $C A P N 1, C A P N 2, C A S T, H S P B 1, D N A J A 1, F A B P 4, S C D$ and PRKAG3 genes in Longissimus Thoracis muscle of Nellore cattle from extreme groups for meat tenderness.

\begin{tabular}{|c|c|c|c|c|}
\hline Gene & Group & Fold Change $^{1}$ & Standard error & p-value \\
\hline \multirow{2}{*}{ CAPN1 } & Tender & 1,00 & 0.15 & \multirow{2}{*}{$0.0143^{*}$} \\
\hline & Tough & 1.47 & 0.15 & \\
\hline \multirow{2}{*}{ CAPN2 } & Tender & 1,00 & 0.2 & \multirow{2}{*}{$0.0009^{* *}$} \\
\hline & Tough & 1.53 & 0.2 & \\
\hline \multirow{2}{*}{$C A S T$} & Tender & 1,00 & 0.15 & \multirow{2}{*}{$0.0183^{*}$} \\
\hline & Tough & 1.33 & 0.15 & \\
\hline \multirow{2}{*}{ HSBP1 } & Tender & 1,00 & 0.17 & \multirow{2}{*}{$0.0225^{*}$} \\
\hline & Tough & 1.43 & 0.17 & \\
\hline \multirow{2}{*}{$D N A J A 1$} & Tender & 1,00 & 0.21 & \multirow{2}{*}{$0.001^{* *}$} \\
\hline & Tough & 1.50 & 0.21 & \\
\hline \multirow{2}{*}{$F A B P 4$} & Tender & 1,00 & 0.4 & \multirow{2}{*}{0.3439} \\
\hline & Tough & 0.51 & 0.4 & \\
\hline \multirow{2}{*}{$S C D$} & Tender & 1,00 & 0.17 & \multirow{2}{*}{0.8859} \\
\hline & Tough & 0.72 & 0.17 & \\
\hline \multirow{2}{*}{$P R K A G 3$} & Tender & 1,00 & 0.31 & \multirow{2}{*}{0.4754} \\
\hline & Tough & 0.54 & 0.31 & \\
\hline
\end{tabular}
group. 


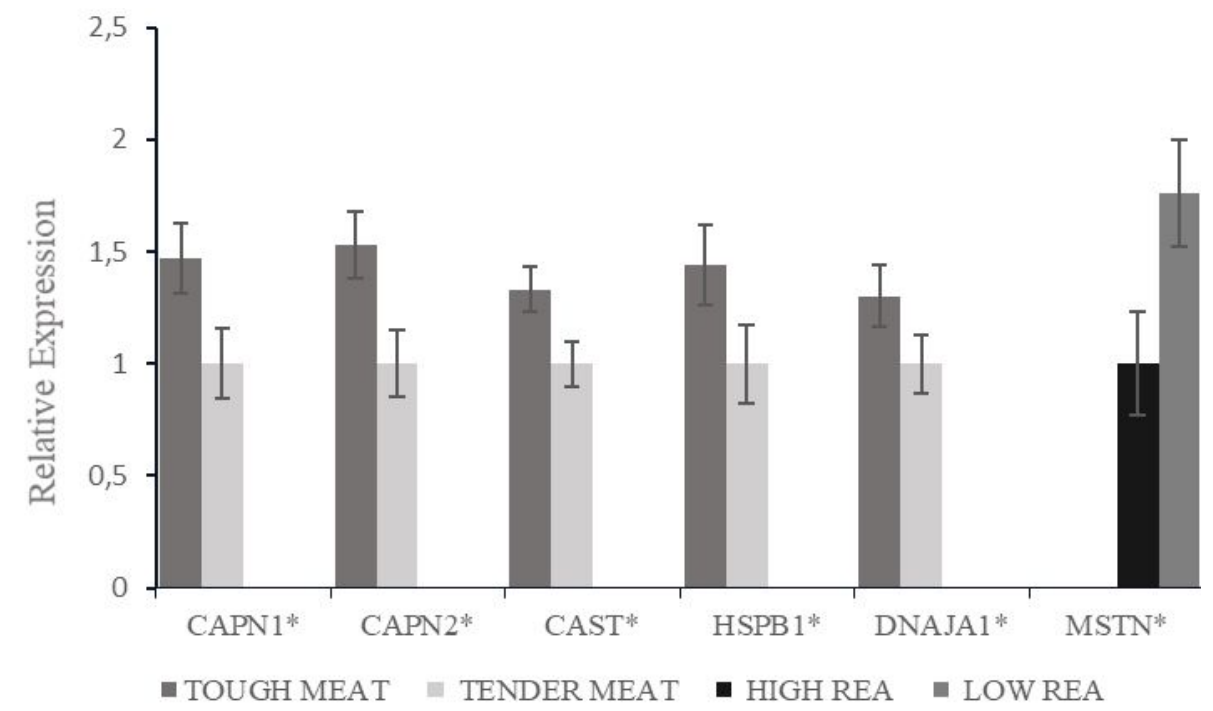

Figure 1: Relative expression of genes in Longissimus thoracis muscle of Nellore animals belonging of groups extremes for meat tenderness (CAPN1, CAPN2, CAST, $H S P B 1$, and DNAJA1 )and ribeye area (MSTN). ("significant at $5 \%)$.

Considering only the differentially expressed genes (CAPN1, CAPN2, CAST, HSPB1, DNAJA1 and MSTN), just the proteins traduced by CAPN1, CAPN2, CAST and $H S P B 1$ were detected, but all of them, showed no significant differences in expression between groups (Table 6). The proteins traduced by DNAJA1 and MSTN were not identified in the analysis.

Table 6: Protein name, uniprot accession number, gene symbol, number of peptides identified, $\log 2$ fold change, $\mathrm{p}$-value and q-value, for proteins whose genes were differentially expressed.

\begin{tabular}{lcccccc} 
Protein name* & UniProt & Gene & Peptides & Log2FC** & P-value & q-value \\
\hline Calpain-1 catalytic subunit & Q27970 & $C A P N 1$ & 57 & 0,199 & 0,69 & 0,73 \\
Calpain-2 catalytic subunit & Q27971 & $C A P N 2$ & 4 & 0,217 & 0,81 & 0,85 \\
Calpastatin & P20811 & $C A S T$ & 10 & $-0,162$ & 0,88 & 0,91 \\
Heat shock protein beta-1 & Q3T149 & HSPB1 & 2462 & $-0,054$ & 0,59 & 0,64 \\
\hline
\end{tabular}

${ }^{*}$ Proteins traduced by DNAJA1 and MSTN were not detected

**The log2 fold-change estimates (relative expression) refer to the tender meat group 


\section{Discussion}

\subsection{REA-related genes}

The gene that encodes myostatin (MSTN) was downregulated in the group with the highest ribeye area (p-value $<0.05$ ) (Table 4). Myostatin, also referred as growth and differentiation factor- 8 , is a protein secreted in muscle tissues that is essential for regulation of skeletal muscle. The highest gene concentrations cause a decrease in normal muscle development and muscle weight loss (Mcpherron and Lee, 1997). Similar results had been reported by Silva et al. (2020), who also observed MSTN was downregulated in the highest ribeye area group in Nellore animals. Likewise, Zhang et al. (2011) found significant differences in gene expression between male and female Quichuan cattle. MSTN was downregulated in the male group compared with the female group, indicating that male cattle had greater muscle protein deposition than females. Since our results showed that MSTN was downregulated in the highest ribeye area group, this gene may contribute to the increased muscle growth in these animals.

The Insulin-like growth factors (IGFs) were not differentially expressed in our study although an association between ribeye area and IGFs genes has been reported in cattle (Goodall and Schmutz et al., 2007; Sadkowski et al., 2009; Guo et al., 2015).The IGF's contribute to cell regulation and stimulate protein synthesis, acting on embryonic and postnatal growth and development (Schmid, 1995). Once the ribeye area is considered a polygenic trait and is highly influenced by several environmental factors, many genes and mechanisms that induce differences in the growth of the Nellore breed are still unknown. Despite the crossing between the taurine and zebu breeds leads to higher carcass yields and ribeye area, as the proportion of zebu genes increases (Mendonça et al., 2021), our results suggest that the expression levels of IGF-1 and IGF-2 genes do not exert a direct effect on REA in Nellore animals of this study and other genes 
are related with the highest ribeye area (Vignato et al., 2017, Silva et al., 2020). No significant differences were found in the expression of NEDD4 (E3 ubiquitin protein ligase) and UBE4A (Ubiquitin conjugation factor E4) genes between the two groups (Table 4). The NEDD4 gene encodes the ubiquitin-ligase protein belonging to the NEDD4 family, while the UBE4A gene plays a fundamental role in the ubiquitination process (Contino et al., 2004). Among the functions of ubiquitin-ligase proteins stand out the support in the protein turnover and in the internationalization of other proteins in the cell. (Cao et al., 2004; Monami et al., 2008; Goel et al., 2015.) Proteins are continually being synthesized and degraded by cells, with growth occurring when the rate of synthesis exceeds the rate of degradation.

Gomes et al. (2013) have already reported that genes related to protein turnover were associated with growth and carcass traits in Nellore cattle. However, Heiderich et al. (2014), using non castrated Nellore bulls, observed that protein turnover decreases as body weight increases (480 kg, weight similar to the animals used in this study). This could explain why these genes were not differentially expressed. The maturity or increase in body weight gradually decreases the synthesis of muscle protein, changing the body composition. Thus, this process leads to a decrease in the percentage of muscle in the body, which could change the turnover rate (Heiderich et al., 2014).

Furthermore, the differences in gene expression observed by Silva et al. (2020) highlight the complexity of the transcriptome in Nellore cattle with divergent ribeye area phenotypes, in addition to the different biological pathways and genes involved with the trait.

\subsection{Genes related to meat tenderness}

The $\mu$-calpain (CAPN1) and m-calpain (CAPN2) genes showed higher expression in animals presenting tough meat (p-value $<0.05$ ) (Table 5). The calpain system in the 
skeletal muscle include at least three calpains ( $\mu$-and m-calpains and calpain 3 ) and a third polypeptide, calpastatin, which acts as specific endogenous inhibitor (Bhat et al., 2018). Calpains act on the degradation of functionally relevant structural proteins such as the myofibrillar proteins (Lana and Zolla., 2016) and are generally identified as the main responsible for the proteolysis and tenderization processes (Bhat et al., 2018) mainly in Bos Taurus cattle (Casas et al., 2006; Corva et al., 2007). There is evidence that the action of CAPN1 occurs during maturation of meat. Carvalho et al. (2012) using qRT-PCR technique found a negative association between CAPN1 gene expression and tenderness of meat without maturation, as well as our study. However, these authors observed that at 14 days of maturation there was a positive association between gene expression and meat tenderness.

One possible explanation is that immediately after slaughter the action of ucalpain is not expected on postmortem proteolysis, but at 14th day of maturation this effect would be evident. Thus, greater expression of these genes in matured meat may be expected. The lack of association between $C A P N 1$ and $C A P N 2$ gene expression levels and meat tenderness shows the complexity of the mechanisms that occur during the tenderization phase. In addition, transcriptome analysis (Gonçalves et al., 2018) and genome-wide associations studies (GWAS) (Tizioto et al., 2013) identified transcripts and metabolic pathways that could be responsible for variation in beef tenderness in Nellore cattle, which differ from those previously identified in Bos Taurus cattle.

Regarding the calpastatin (CAST) gene, the expression was significantly upregulated in tough meat when compared to the tender meat ( $p$-value $<0.05$ ). Calpastatin acts inhibiting calpain by preventing the calpain proteolytic activation and the expression of catalytic activity (Lonergan et al., 2010). These results suggest that despite the highest expression of calpains in tough meat, the inhibitory activity of calpastatin was responsible 
341 for blocking the active site of calpains and inhibiting its activity (Kawasaki and

342 Kawashima, 1996; Lonergan et al., 2010). Several studies have shown that the lowest tenderness of zebu beef could be due to the greatest calpastatin activity, inhibiting the proteolytic activity of calpain (Whipple et al., 1990; Wheeler et al., 1994; Nattrass et al., 2014). Moreover, the highest calpastatin activity has been considered one of the main factors related to lower zebu beef tenderness compared to taurine (Whipple et al., 1990). Thus, the antagonistic action between the components of the proteolytic system suggests that the greater the activity of calpastatin in the muscle, the lower the action of calpain and therefore the tenderness of the meat.

The results found in the present study for calpain / calpastatin complex suggest that low meat tenderness could be attributed in part to the high expression of calpastatin gene. However, other metabolic pathways that involve different genes are possibly involved in the meat tenderness process (Nagai, 2015; Fonseca et al., 2017).

For genes (HSPBI and DNAJA1) that encode heat shock proteins (HSPs), the higher expression was observed in tough meat (Table 5), showing a negative association tenderization process (Bernard et al., 2007; Lomiwes et al., 2014; Malheiros et al., 2018). The negative association of HSPB1 and beef tenderness has been reported in other studies of gene and protein expression (Kim et al., 2008; Malheiros et al., 2018). Probably the The DNAJA1 gene, also downregulated for meat tenderness, encodes a member heat shock protein family (HSP70). The HSP40/HSP70 complex directly inhibits 
apoptosis retarding cellular death during the conversion of muscle into meat and consequently to lowering meat tenderization (Bernard et al., 2007; Picard et al., 2010). Our results corroborate with Malheiros et al. (2018) and Bernard et al. (2007) who observed negative association of this gene with meat tenderness in Nellore and Charolais cattle, respectively.

The FABP4 (Fatty acid-binding protein) and $S C D$ genes (Acyl-CoA desaturase), related to lipidic metabolism, were not differentially expressed in the present study (Table 5). In contrast, using microarray on muscle tissue of divergent Angus animals for tenderness, Zhao et al. (2012) found that both genes (FABP4 and SCD) were upregulated to meat tenderness. These authors worked with Angus animals (Bos taurus) which naturally have more tender and marbling meat when compared to Bos indicus animals (Whipple et al., 1990; Cunduff et al., 1992; Wheeler et al., 1994). Furthermore, Rodrigues et al. (2014) using proteomic approach found that proteins involved in contraction, muscle organization and heat shock proteins might be associated with differences in beef quality between Angus (Bos Taurus) and Nellore (Bos indicus). Crouse et al. (1989) studying crossbred animals with different ratios of zebu / taurine genes concluded that as the proportion of zebu genes increased, there was an increase in shear force and a decrease in meat marbling. In addition, Koohmaraie et al. (2002) suggested that only $15 \%$ of the variation in beef tenderness is due to differences in marbling and collagen levels and remaining $85 \%$ may be attributed to the postmortem enzymatic actions.

For PRKAG3 gene, no significant difference in expression was observed between groups (Table 5). Previous studies have indicated that the PRKAG3 gene affects the glycogen content in muscle and hence, meat quality traits such the tenderness (Milan et al., 2000; Ciobanu et al., 2001; Bongiorni et al., 2016). In contrast to our results, Bongiorni et al. (2016) found four isoforms of the PRKAG3 gene that were differentially 
expressed in a transcriptome study of meat tenderness in two Italian cattle breeds. In muscle, the glycogen content affects the ultimate $\mathrm{pH}$ and consequently the postmortem maturation process. Thus, this distinct pattern of $P R K A G 3$ gene expression could indicate impaired glycogen storage in skeletal muscle, and consequently influence meat tenderness. However, our results suggest that regardless the animal group, there seems to be no deficiency in glycogen storage that influences meat tenderness. Thus, probably the greater or lesser tenderness would be due other metabolic pathways that involve other different genes (Fonseca et al., 2017).

\subsection{Protein expression for genes differentially expressed}

Despite being identified, the proteins encoded by the genes calpain and calpastatin were not differentially expressed between contrasting groups for meat tenderness (table 6). As discussed, calpains compound a family of proteolytic proteins involved in myofibrillar degradation and meat tenderization during aging whereas calpastatin acts as a natural inhibitor of the protease calpain (Bhat et al., 2018). Dias et al. (2016) aiming to quantify the enzymes $\mu$-calpain, m-calpain and calpastatin within contrasting meat tenderness groups, found no significant difference on the amount of enzyme $\mu$ and $\mathrm{m}$ calpain. However, there was a higher calpastatin activity in animals of tough meat group. Additionally, Rodrigues et al. (2017) comparing the muscle proteomic profile of Angus and Nellore also have not detected differences in the abundance of calpastatin and calpain. However, in a parallel study with the same animals used by Rodrigues et al. (2017), there was a higher calpastatin activity in Nellore beef (Duarte et al., 2013).

Although the genes encoding these proteins have been differentially expressed, the post-transcriptional and translational gene regulatory mechanisms directly influence the final protein production. Moreover, a proteome is a highly dynamic entity and protein expression in a biological system constantly changes. In view of the above, we cannot 
exclude the role of the enzyme calpastatin in the lesser tenderness of the meat, since the enzyme was more expressed in tough meat in Real-Time PCR analysis.

The protein encoded by HSPB1 gene was not differentially expressed between the groups for meat tenderness, while the protein encoded by DNAJA1 gene was not identified in the samples studied. Contrasting results from proteomic studies are found in the literature. Guillemin et al. (2011) observed that both heat shock proteins encoding by HSPB1 and DNAJA1 genes, were positively correlated with highest meat tenderness in Charolais cattle. Probably is this case, the structural proteins protection was a positive factor in the tenderization process by inhibiting the formation of aggregates and favoring proteolysis (Guillemin et al., 2011). Nonetheless, Kim et al. (2008) observed an increase of HSP27 protein, encoding by HSPB1 gene, in native Korean cattle with tough meat. Similarly, Morzel et al. (2008) observed a decrease in the amount of HSP27 after 14 days of aging in young bulls, which was correlated with meat tenderness. Probably the negative regulation of HSP27 may increase the degradation of muscle proteins and consequently improve meat tenderness, since one of the functions that HSPB1 is maintain the protein integrity and difficult to proteolytic degradation of myofibrillar proteins.

Although the genes encoding the heat shock proteins (HSPB1 and DNAJA1) were differentially expressed between the groups for meat tenderness, the same was not observed for the expression of the proteins encoded by them. These results suggest once again that gene regulation mechanisms may act influencing protein production. Moreover, the proteome of the cell is constantly changing reflecting the immediate environment of the protein.

Myostatin, a protein synthesized and secreted by skeletal muscle that negatively regulates muscle mass, was not identified in proteomic analyses. Loss-of-function 
mutations in the MSTN gene are known to cause an extreme 'double muscling' phenotype in cattle. (Mcpherron and Lee, 1997)

The central dogma of molecular biology deals with the transfer of information from DNA via mRNA to proteins. It is mechanically well known how genes are transcribed, and the mRNA processed and sequentially translated into proteins. However, most reports of mRNA and protein abundance find only a weak correlation between the respective abundances of these two classes of biological molecules (Greenbaum et al., 2003; Maier et al., 2009).

As showed by Lehninger et al. (2010), when the messenger RNA leaves the cell nucleus, it may or may not is translated to proteins, being susceptible to various posttranscriptional and post-translational regulatory factors that mediate protein production. Moreover, stability is a big factor to explain the divergence between molecules. The proteins are in a constant process of turnover which makes half-lives highly variable. significant amount of error and noise in both protein and mRNA trials that limit the possibility to get a totally clear result (Greenbaum et al., 2003). However, despite proteomics and transcriptomics data have almost no overlap, the integrative analysis of biological pathways influencing meat quality traits can help to elucidate the biological processes and gene networks involved in the phenotype expression. Moreover, a single gene or protein is not directly responsible for meat tenderness or ribeye area, but rather a group of genes and proteins that play a role together in their pathways to favor the meat quality process.

\section{Conclusion}

Our results could confirm the potential of some studied genes as biomarkers for carcass and meat quality in Nellore cattle. The highest expression of calpain gene in tough 
meat indicate inconsistencies regarding calpain mRNA activity and meat tenderness trait

466 in Nellore. The selected genes did not show differential protein expression, suggesting

467 that several factors may influence in the transcription and translation processes.

\section{Ethics statement}

469

470

471

472

473

474

475

476

477

478

479

480

481

482

483

484

All experimental procedures involving animals were approved by Ethics Committee of the São Paulo State University (UNESP), School of Agricultural and Veterinarian Sciences, Jaboticabal, SP, Brazil (CEUA protocol:005622/17).

\section{Consent for publication}

Not applicable.

\section{Availability of data and materials.}

The dataset utilized in this study belong to the Cia do Melhoramento animal breeding program company and could be available on request. The author does not have authorization to share the data.

\section{Competing interests}

The authors declare no competing interests.

\section{Funding}

This study was supported by the São Paulo Research Foundation (FAPESP, grants 2017/10630-2, 2018/20026-8 and 2016/23937-6).

\section{Acknowledgments}

This study was supported by the São Paulo Research Foundation (FAPESP, grants 2017/10630-2, 2018/20026-8 and 2016/23937-6). We thank to the Cia de Melhoramento animal breeding program for providing the tissue samples and database used in this study.

\section{References}

BHAT, Z. F. et al. Role of calpain system in meat tenderness: A review. Food Science and Human Wellness, v. 7, n. 3, p. 196-204, 2018. 
491

492

493

494

495

496

497

498

499

500

501

502

503

504

505

506

507

508

509

510

511

512

513

514

515

516

517

518

519

520

521

522

523

524

525

526

527

528

529

530

531

532

533

BENDIXEN, E. The use of proteomics in meat science. Meat science, v. 71, n. 1, p. 138149,2005

BERNARD, C. et al. New indicators of beef sensory quality revealed by expression of specific genes. Journal of Agricultural and Food Chemistry, Washington, DC, v. 55, n. 13, p. 5229-5237, 2007.

BONGIORNI, S. et al. Transcriptomic investigation of meat tenderness in two Italian cattle breeds. Animal genetics, v. 47, n. 3, p. 273-287, 2016.

BRADFORD, M. M. A rapid and sensitive method for the quantitation of microgram quantities of protein utilizing the principle of protein-dye binding. Analytical biochemistry, v. 72, n. 1-2, p. 248-254, 1976

BUSATO, K. C. et al. Expression of genes related to the regulation of muscle protein turnover in Angus and Nellore bulls. Journal of animal science, v. 94, n. 4, p. 14721481, 2016.

CAO, X. R. et al. Nedd4 controls animal growth by regulating IGF-1 signaling. Science signaling, v. 1, n. 38, p. ra5-ra5, 2008.

CARVALHO, M.E. Estudo de genes associados com a maciez da carne em bovinos da raça Nellore. 2012. Tese (Doutorado em Zootecnia) - Universidade de São Paulo Escola Superior de Agricultura "Luiz de Queiroz" Piracicaba. 2012.

CARVALHO, M. E. et al. Heat shock and structural proteins associated with meat tenderness in Nellore beef cattle, a Bos indicus breed. Meat science, v. 96, n. 3, p. 13181324, 2014.

CASAS, E. et al. Effects of calpastatin and $\mu$-calpain markers in beef cattle on tenderness traits. Journal of Animal Science, Champaign, v. 84, n. 3, p. 520-525, 2006.

CIOBANU, D. et al. Evidence for new alleles in the protein kinase adenosine monophosphate-activated $\gamma 3$-subunit gene associated with low glycogen content in pig skeletal muscle and improved meat quality. Genetics, v. 159, n. 3, p. 1151-1162, 2001.

CONTINO, G. et al. Expression analysis of the gene encoding for the U-box-type ubiquitin ligase UBE4A in human tissues. Gene, v. 328, p. 69-74, 2004.

CORAZZIN, M, et al. Activity of enzymes and expression of genes involved in beef tenderization in two bovine skeletal muscles. ICOMST2013. E-book of proceedings, p. 0-12, 2013. 
CORVA, P. et al. Association of CAPN1 and CAST gene polymorphisms with meat tenderness in Bos taurus beef cattle from Argentina. Genetics and Molecular Biology, v. 30, p. 1064-1069, 2007.

CROUSE, J. D.; CUNDIFF, L. V.; KOCH, R. M. Comparisons of Bos indicus and Bos taurus inheritance for carcass beef characteristics and meat palatability. Journal of Animal Science, Champaign, v. 67, n. 10, p. 2661-2668, 1989.

CUNDUFF, L. V. Genetic selection to improve the quality and composition of beef carcasses. Reciprocal Meat Conference Proceedings, Savoy, v. 45, p. 123-131, 1992.

CURI, R. A. et al. Effect of single nucleotide polymorphisms of CAPN1 and CAST genes on meat traits in Nellore beef cattle (Bos indicus) and in their crosses with Bos taurus. Animal Genetics, Chichester, v. 40, n. 4, p. 456-462, 2009.

DIAS, V. A. D. Expressão das proteínas calpaína e calpastatina e suas relações com a qualidade da carne de bovinos da raça Nellore (Bos indicus). 2016. Tese (Doutorado em Zootecnia) - Faculdade de Ciências Agrárias e Veterinárias “Júlio de Mesquita Filho", Jaboticabal. 2016.

DUARTE M. S. et al. Calpastatin activity and beef tenderness of Nellore and Angus cattle fed two feeding strategies. Proceedings of the 59th International Congress of Meat Science and Technology; 2013 Aug 18-23; Izmir, Turkey. Izmir: Ege University, Food Engineering Development; 2013.

FANG, X. et al. Comparative transcriptome profile of genes differentially expressed in longissimus dorsi muscles between Japanese black (Wagyu) and Chinese Red Steppes cattle. Journal of Animal Science, v. 96, n. 3, p. 134-135, 2018.

FERRAZ, J. B. S.; FELÍCIO, P. E. Production systems-An example from Brazil. Meat science, Amsterdam, v. 84, n. 2, p. 238-243, 2010.

FONSECA, L. F. S. et al. Expression of genes related to mitochondrial function in Nellore cattle divergently ranked on residual feed intake. Molecular biology reports, v. 42, n. 2 , p. $559-565,2015$.

FONSECA, L. F. S. et al. Differences in global gene expression in muscle tissue of Nellore cattle with divergent meat tenderness. BMC Genomics, London, v. 18, n. 945, 2017.

GLICKMAN, M. H.; CIECHANOVER, A. The ubiquitin-proteasome proteolytic pathway: destruction for the sake of construction. Physiological reviews, v. 82, n. 2, p. 373-428, 2002. 
577 GREENBAUM, D. et al. Comparing protein abundance and mRNA expression levels on a genomic scale. Genome biology, v. 4, n. 9, p. 117, 2003.

GREGORI, J.; SANCHEZ, A.; VILLANUEVA, J. MsmsTests: LC-MS/MS Differential Expression Tests. R package version, v. 1, n. 0, 2019.

582

GOEL, P.; MANNING, J. A.; KUMAR, S. NEDD4-2 (NEDD4L): the ubiquitin ligase for multiple membrane proteins. Gene, v. 557, n. 1, p. 1-10, 2015.

GONÇALVES, T. M. et al. Gene co-expression analysis indicates potential pathways and regulators of beef tenderness in Nellore cattle. Frontiers in genetics, v. 9, p. 441, 2018.

GOODALL, J. J.; SCHMUTZ, S. M. IGF-2 gene characterization and association with rib eye area in beef cattle. Animal Genetics, Chichester, v. 38, n. 2, p. 154-161, 2007.

GUILLEMIN, N. et al. Functional analysis of beef tenderness. Journal of Proteomics, Amsterdam, v. 75, n. 2, p. 352-365, 2011.

GUO, B. et al. Transcriptome analysis of cattle muscle identifies potential markers for skeletal muscle growth rate and major cell types. BMC Genomics, London, v. 16, n. 1, p. $177,2015$.

HEID, C. A. et al. Real time quantitative PCR. Genome research, v. 6, n. 10, p. 986994, 1996.

HEIRERICH, D. Efeito do estágio fisiológico sobre a taxa de turnover proteico e as exigências de proteína para mantença de Bovinos Nelore. Dissertação (Mestrado em Zootecnia) - Universidade Federal de Lavras. Lavras. 2013.

HORODYSKA, J. et al. Analysis of meat quality traits and gene expression profiling of pigs divergent in residual feed intake. Meat science, v. 137, p. 265-274, 2018.

HOLLUNG, K. et al. Application of proteomics to understand the molecular mechanisms behind meat quality. Meat science, v. 77, n. 1, p. 97-104, 2007.

HOCQUETTE, J. F. et al. The GENOTEND chip: a new tool to analyse gene expression in muscles of beef cattle for beef quality prediction. BMC Veterinary Research, v. 8, n. 1, p. $135,2012$.

KAWASAKI, H.; KAWASHIMA, S. Regulation of the calpain-calpastatin system by membranes. Molecular membrane biology, v. 13, n. 4, p. 217-224, 1996.

KIM, N. K. et al. Proteins in longissimus muscle of Korean native cattle and their relationship to meat quality. Meat Science, v. 80, n. 4, p. 1068-1073, 2008. 
KOOHMARAIE, M. et al. Meat tenderness and muscle growth: is there any relationship? Meat Science, Amsterdam, v. 62, n. 3, p. 345-352, 2002.

LAGE, J. F. et al. Influence of genetic type and level of concentrate in the finishing diet on carcass and meat quality traits in beef heifers. Meat Science, v. 90, n. 3, p. 770-774, 2012.

LANA, A.; ZOLLA, L. Proteolysis in meat tenderization from the point of view of each single protein: a proteomic perspective. Journal of Proteomics, Amsterdam, v. 147, p. 85-97, 2016.

LEHNERT, S. A. et al. Gene expression studies of developing bovine longissimus muscle from two different beef cattle breeds. BMC Developmental Biology, London, v. 7, n. 1, p. 95, 2007.

LEHNINGER, A. L.; NELSON, D. L.; COX, M. M. Princípios de bioquímica. 2. ed. São Paulo: Sarvier, 2000. 839 p.

LI, X. J. et al. Identification of genes in longissimus dorsi muscle differentially expressed between Wannanhua and Yorkshire pigs using RNA-sequencing. Animal genetics, v. 47, n. 3, p. 324-333, 2016.

LOMIWES, D. et al. Small heat shock proteins and their role in meat tenderness: A review. Meat Science, Amsterdam, v. 96, n. 1, p. 26-40, 2014.

LONERGAN, E. H.; ZHANG, W.; LONERGAN, S. M. Biochemistry of postmortem muscle-Lessons on mechanisms of meat tenderization. Meat science, v. 86, n. 1, p. 184$195,2010$.

MAGALHÃES, A. F. B. et al. Genome-wide association study of meat quality traits in Nellore cattle. PloS One, San Francisco, v. 11, n. 6, p. 15-45, 2016.

MALHEIROS, J. M. et al. Association of CAST2, HSP90AA1, DNAJA1 and HSPB1 genes with meat tenderness in Nellore cattle. Meat science, v. 138, p. 49-52, 2018.

MAIER, T.; GÜELL, M.; SERRANO, L. Correlation of mRNA and protein In complex biological samples. FEBS letters, v. 583, n. 24, p. 3966-3973, 2009.

MCPHERRON, A. C.; LEE, S. J. Double muscling in cattle due to mutations in the myostatin gene. Proceedings of the National Academy of Sciences, Washington, DC, v. 94, n. 23, p. 12457-12461, 1997. 
MENDONÇA, F. S. et al. Breed direct, maternal and heteros is effects due to Angus, Caracu, Hereford and Nelore on carcass and meat quality traits of cull cows. Livestock Science, v. 243, p. 104374, 2021.

MILAN, D. et al. A mutation in PRKAG3 associated with excess glycogen content in pig skeletal muscle. Science, v. 288, n. 5469, p. 1248-1251, 2000.

MISZTAL, I. et al. Manual for BLUPF90 family of programs. Athens: University of Georgia, 2014.

MONAMI, G.; EMILIOZZI, V.; MORRIONE, A. Grb10/Nedd4-mediated multiubiquitination of the insulin-like growth factor receptor regulates receptor internalization. Journal of cellular physiology, v. 216, n. 2, p. 426-437, 2008.

MORENO, M. A. et al. Polymorphisms of calpain gene in Colombian Creole cattle. Livestock Research for Rural Development, v. 21, n. 6, 2009.

MORZEL, M. et al. Muscle proteome and meat eating qualities of Longissimus thoracis of "Blonde d'Aquitaine" young bulls: A central role of HSP27 isoforms. Meat Science, v. 78, n. 3, p. 297-304, 2008.

NAGAI, L. A. E. Identificação de genes relacionados à maciez da carne de bovinos das raças Angus e Nellore por análise de expressão diferencial. 2015. Dissertação (Mestrado em Genética e Biologia Molecular) - Universidade Estadual de Campinas, Campinas, 2015.

NATTRASS, G. S. et al. A post-transcriptional mechanism regulates calpastatin expression in bovine skeletal muscle. Journal of Animal Science, Champaign, v. 92, n. 2, p. 443-455, 2014.

PAGE, B. T. et al. Evaluation of single-nucleotide polymorphisms in CAPN1 for association with meat tenderness in cattle. Journal of Animal Science, Champaign, v. 80, n. 12, p. 3077-3085, 2002.

PAN, P. W. et al. Identification of differentially expressed genes in the Longissimus Dorsi muscle tissue between Duroc and Erhualian pig by mRNA differential display. Asian Australasian Journal of Animal Science, Champaign, v. 16, n. 7, p. 1066-1070, 2003.

PEREIRA, A. S. C. et al. Growth performance, and carcass and meat quality traits in progeny of Poll Nellore, Angus and Brahman sires under tropical conditions. Animal production science, v. 55, n. 10, p. 1295-1302, 2015.

PICARD, B. et al. Skeletal muscle proteomics in livestock production. Briefings in Functional Genomics, Oxford, v. 9, n. 3, p. 259-278, 2010. 
PINTO, L. F. B. et al. Association of SNPs on CAPN1 and CAST genes with tenderness in Nellore cattle. Genetics and Molecular Research, Ribeirão Preto, v. 9, n. 3, p. 1431$1442,2010$.

PIÓRKOWSKA, K. et al. Genome-wide RNA-Seq analysis of breast muscles of two broiler chicken groups differing in shear force. Animal genetics, v. 47, n. 1, p. 68-80, 2016.

RAUCH, A. et al. Computational Proteomics Analysis System (CPAS): an extensible, open-source analytic system for evaluating and publishing proteomic data and high throughput biological experiments. Journal of proteome research, v. 5, n. 1, p. 112-121, 2006.

RODRIGUES, R. T. S. et al. Differences in beef quality between Angus (Bos taurus taurus) and Nellore (Bos taurus indicus) cattle through a proteomic and phosphoproteomic approach. PloS one, v. 12, n. 1, p. e0170294, 2017.

SADKOWSKI, T. et al. Comparison of skeletal muscle transcriptional profiles in dairy and beef breeds bulls. Journal of Applied Genetics, Heidelberg, v. 50, n. 2, p. 109-123,

SCHMID, C. Insulin: like growth factors. Cell Biology International, Garsington, Oxford, v. 19, n. 5, p. 445-457, 1995.

SCHROEDER, A. et al. The RIN: an RNA integrity number for assigning integrity values to RNA measurements. BMC Molecular Biology, London, v. 7, n. 1, p. 3, 2006.

SILVA, D. B. et al. Transcriptome profiling of muscle in Nelore cattle phenotypically divergent for the ribeye muscle area. Genomics, v. 112, n. 2, p. 1257-1263, 2020.

STEIBEL, J. P. et al. A powerful and flexible linear mixed model framework for the analysis of relative quantification RT-PCR data. Genomics, v. 94, n. 2, p. 146-152, 2009.

TIZIOTO, P. C. et al. Genome scan for meat quality traits in Nellore beef cattle. Physiological Genomics, Rockville, v. 45, n. 21, p. 1012-1020, 2013.

USDA (UNITED STATES DEPARTMENT OF AGRICULTURE); AGRICULTURAL MARKETING SERVICE; LIVESTOCK POULTRY AND SEED PROGRAM. United States standards for grades of carcass beef. Washington, DC, 1989. $16 \mathrm{p}$.

VANDESOMPELE, J.; et al. Accurate normalization of real-time quantitative RT-PCR data by geometric averaging of multiple internal control genes. Genome Biology, London, v. 3, n. 7, 2002. 
750 VIGNATO, B.S. et al. Comparative muscle transcriptome associated with carcass traits of Nellore cattle. BMC Genomics, London, v. 18, n. 1, p. 506, 2017.

752

WHEELER, T. L.; CUNDIFF, L. V.; KOCH, R. M. Effect of marbling degree on beef 754 palatability in Bos taurus and Bos indicus cattle. Journal of Animal Science, Champaign, v. 72, n. 12, p. 3145-3151, 1994.

756

WHEELER, T. L.; KOOHMARAIE, M.; SHACKELFORD, S. D. Standardized Warner-Bratzler shear force procedures for meat tenderness measurement. Manhattan: G-R Manufacturing Company, 1995. Available:

760 http://192.133.74.26/MRU WWW/protocol/WBS.html. 1995. Access on: outubro de 761 2019.

762

WHIPPLE, G. et al. Evaluation of attributes that affect longissimus muscle tenderness in 764 Bos taurus and Bos indicus cattle. Journal of Animal Science, Champaign, v. 68, n. 9,

765

766

767

768

769

770

771

772 p. 2716-2728, 1990.

WHITE, S. N. et al. A new single nucleotide polymorphism in CAPN1 extends the current tenderness marker test to include cattle of Bos indicus, Bos taurus, and crossbred descent. Journal of Animal Science, Champaign, v. 83, n. 9, p. 2001-2008, 2005.

ZHANG, Y. Y.; ZAN, L.; WANG, H. Screening candidate genes related to tenderness trait in Qinchuan cattle by genome array. Molecular Biology Reports, v. 38, n. 3, p. 2007-2014, 2011.

ZHAO, C. et al. Muscle transcriptomic analyses in Angus cattle with divergent tenderness. Molecular Biology Reports, v. 39, n. 4, p. 4185-4193, 2012. 